\title{
Length-weight relationship and condition factor of tropical sand goby, Acentrogobius caninus (Valenciennes 1837) from Pabean Bay, West Java, Indonesia
}

\author{
Lenny S. Syafei ${ }^{1, *}$ \\ ${ }^{1}$ Indonesian Ichthyological Society, Research Center for Biology, The National Research and \\ Innovation (BRIN), West Java, Indonesia
}

\begin{abstract}
This study aims to determine the length-weight relationship $(L W R)$ and evaluate the condition factors of the tropical sand goby, Acentrogobius caninus (Valenciennes 1837), in Pabean Bay West Java, Indonesia. The sampling was carried out once a month from January to December 2015, and during that period, 152 samples were collected. The $\mathrm{LWR}$ is $\mathrm{W}=9 \times 10^{-6} \mathrm{~L}^{-3.0356}$. The growth pattern of tropical sand goby is isometric $(b=3)$. The monthly relative condition factor ranged from 0.798 to 1.322 (average: 1.028 ).
\end{abstract}

\section{Introduction}

One of the essential parameters in fish biology and stock estimation is the length-weight relationship (LWR) [1]. The equation of this relationship helps in estimating the weight of a fish from its length. Fish biomass is often calculated from its abundance based on length using LWR [2]. Many researchers have reported on the LWR of fish in an area or waters, among others: [3-6]. On the other hand, many articles highlight the LWR of only one type of fish, for example: [7-11].

The value that indicates fish fatness in their habitat is called the condition factor. From a nutritional point of view, the conditional factors are fat accumulation and gonadal development [1]. Condition factors indirectly indicate the physiological condition of fish that receives the influence of intrinsic factors (gonad development and fat stores) and extrinsic factors (availability of food resources and environmental stress) [12]. Furthermore, [13-14] stated that the condition factor provides information on when the fish spawn and proved that conditional factors help evaluate the presence of various fish spawning areas.

Summarily, it can be said that the condition factor is an efficient instrument and shows changes in fish conditions throughout the year [15]. Hence the study of conditional factors is vital for understanding the life cycle of fish and contributing to fish management and thus contributing to the control of ecosystem balance [16]. Meanwhile, [17] discovered that in European Bullheads (Cottus gobio L.), there was a correlation between genetic diversity and condition factors in Flanders, Northern Belgium, but not the case for European bullheads

\footnotetext{
*Corresponding author: lenny.syafei@gmail.com
} 
in Germany. Other researchers [18] stated that the condition factor decreased when the gonadal maturity level of the broodfish (Siganus rivulatus) increased. The condition factor of fish in polluted areas is lower than those in unpolluted and clean regions [19].

Pabean Bay is estuary waters where are located at the springhead of the Cimanuk River. The Bay is packed with mangrove vegetation. The estuary is used for spawning, nurturing, and foraging for food, and Pabean Bay is a habitat for various fish species. One fish species in these waters is the Tropical Sand Goby (Acentrogobius caninus) (Fig. 1). The Tropical Sand Goby is an affordable and essential fish in Pabean Bay.

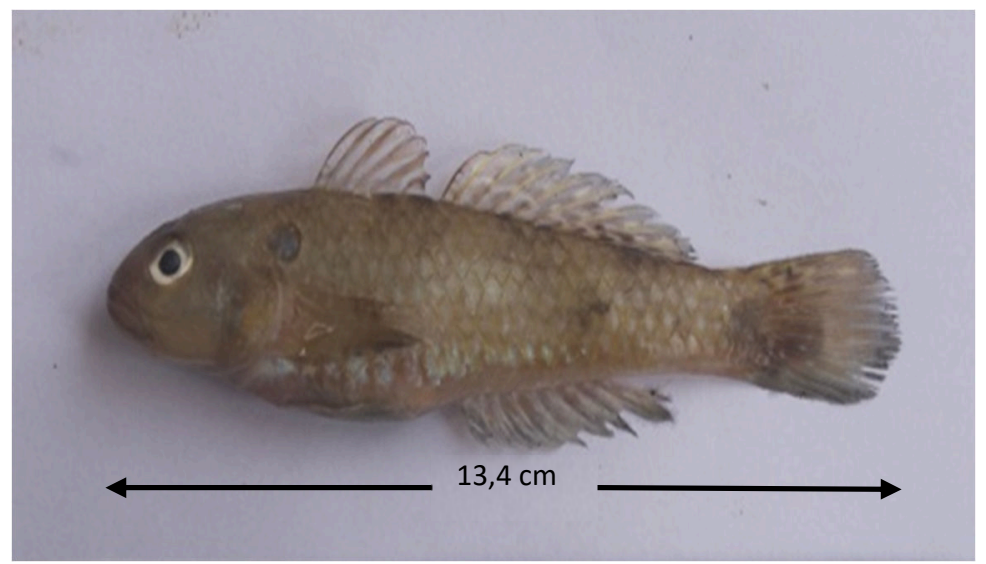

Fig. 1. Tropical sand goby, Acentrogobius caninus (Valenciennes 1837).

This fish's ecological and biological aspects have not been widely acknowledged, along with the LWR and condition factors. However, the fish LWR that was reported was found in the Payra River, Southern Bangladesh [21], mangrove forest of Zhanjiang, China [22], and the East China Sea [23].

The purpose of this study is to determine the length-weight relationship and evaluate the condition factor of tropical sand goby and the influencing factors in the waters of Pabean Bay, West Java, Indonesia.

\section{Materials and methods}

The fishing was done once a month, from January to December 2015. The samplings were carried out in three zones in Pabean Bay, West Java (Fig. 2). Zone one is located in the bay, which is still dominated by fresh water and abundant mangrove vegetation and milkfish ponds. Zone two is located in front of the river mouth and is influenced by freshwater input and sea tides. Zone three is located in the outer region of the bay, bordering the high seas and affected by waves.

Two types of fishing gear are used, Gillnet and Sero (trap, guiding barrier). Gillnet with mesh sizes between 1.5 to 1.75 inches, $400 \mathrm{~m}$ long, and $1.5 \mathrm{~m}$ high. The Gill nets were utilized by spreading the traps in each watering zone and leaving for one hour. Sero, with a mesh size of $1 \mathrm{~mm}$ and a height of $1 \mathrm{~m}$. Sero is placed by fishermen in the afternoon and lifted in the morning. Sero consists of forming several pieces of bamboo till one meter. So that, this method will lead fish to the trap. The working principle of the Sero is operated by blocking the fish and directing the fish to enter the trap, and heading towards the final fishing bag. 


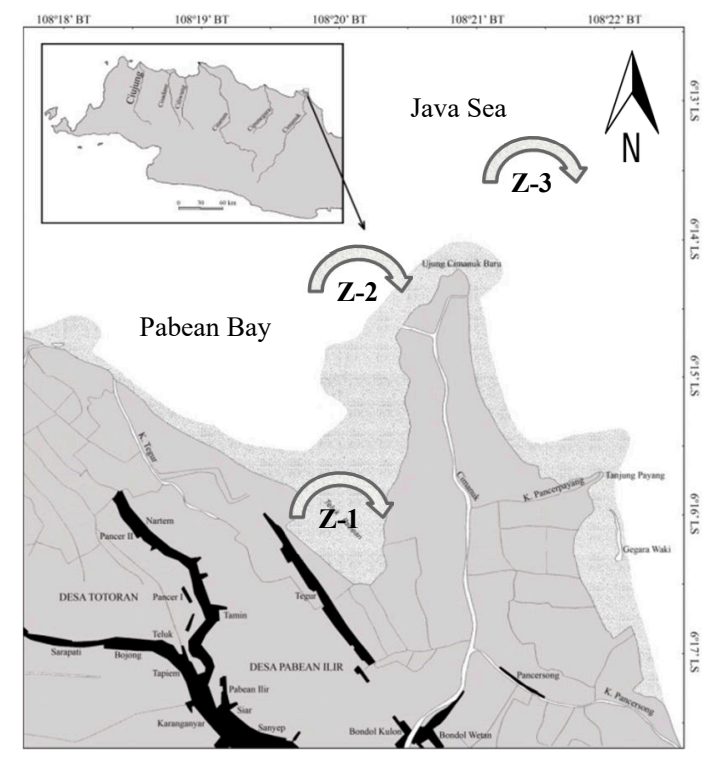

Fig. 2. Maps of locations, Pabean Bay, West Java, Indonesia. Z-1, Z-2, Z-3: sampling station.

The caught fish is then preserved in a $5-10 \%$ formalin solution for later analysis in the laboratory. Each fish sample was then measured in total length (from the tip of the nose to the tip of the most extended tail fin) to the nearest millimeter and weighed to the nearest gram. These data were used to establish the $L W R$ of fish and fish condition factors.

$$
\mathrm{W}=\mathrm{a} \mathrm{L}^{\mathrm{b}}
$$

$\mathrm{W}=$ fish weight $($ gram)

$\mathrm{L}=$ fish length (mm)

The relative condition factor $(\mathrm{Kn})$ is calculated using the following equation:

$$
\mathrm{Kn}=\mathrm{W} / \mathrm{aL}^{\mathrm{b}}
$$

$\mathrm{W}=$ observed fish weight (gram)

$\mathrm{L}=$ fish length $(\mathrm{mm})$

\section{Results}

The number of fish caught during the study was 152 . The fish length ranges from 43 to 148 $\mathrm{mm}$ and weights from 0.6 to 30.28 grams. The equation model of the relationship between length (L) and weight (W) of fish is $\mathrm{W}=9.10^{-6} \mathrm{~L}^{3.0356}$ with $\mathrm{r}=0.9130$ (Fig. 3). 


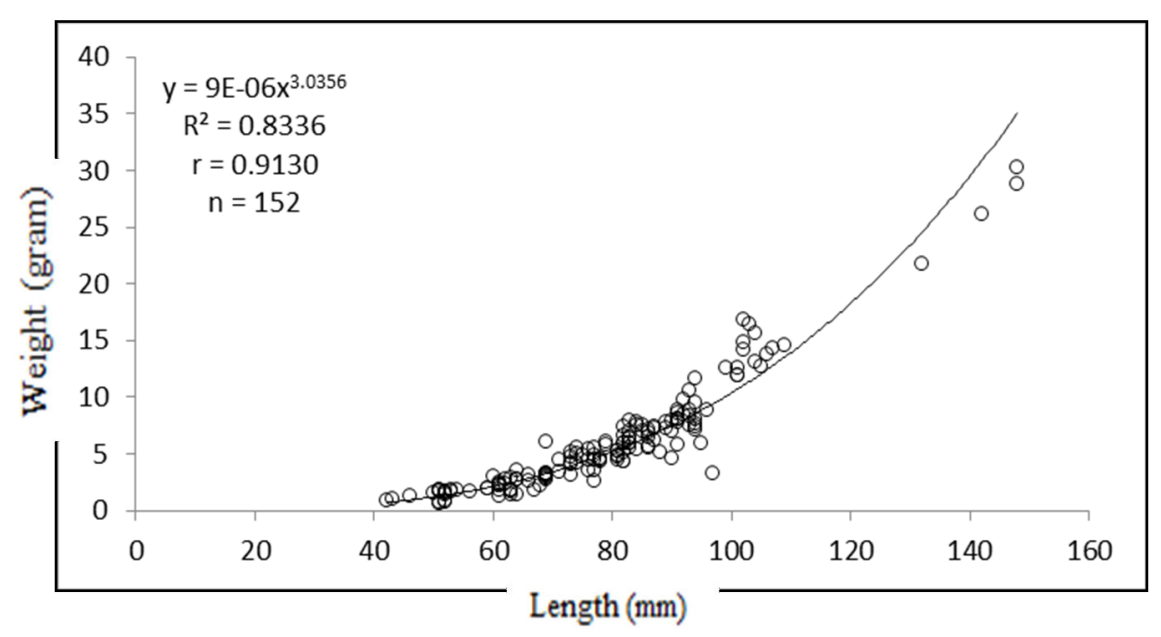

Fig. 3. Length-Weight relationship of tropical sand goby in the waters of Pabean Bay, West Java.

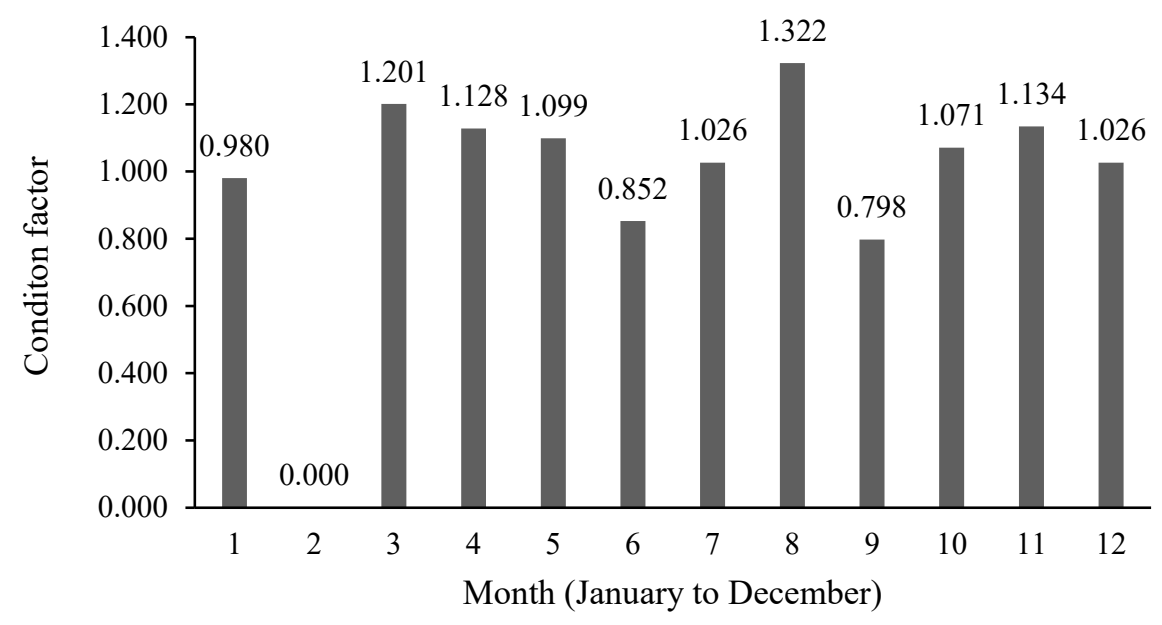

Fig. 4. Monthly fluctuation of condition factor value of tropical sand goby in the water of Pabean Bay, West Java.

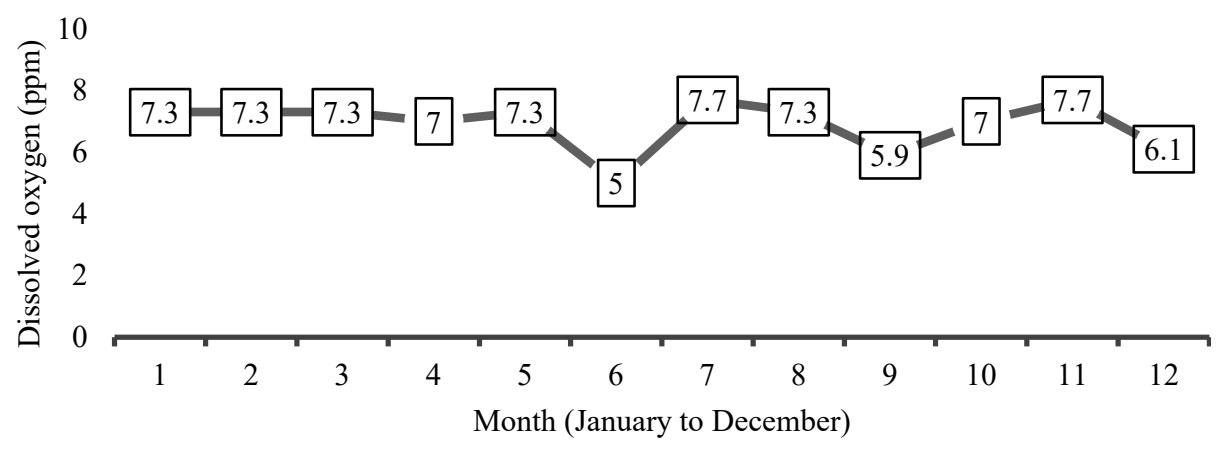

Fig. 5. Monthly fluctuation of dissolved oxygen in the waters of Pabean Bay, West Java. 


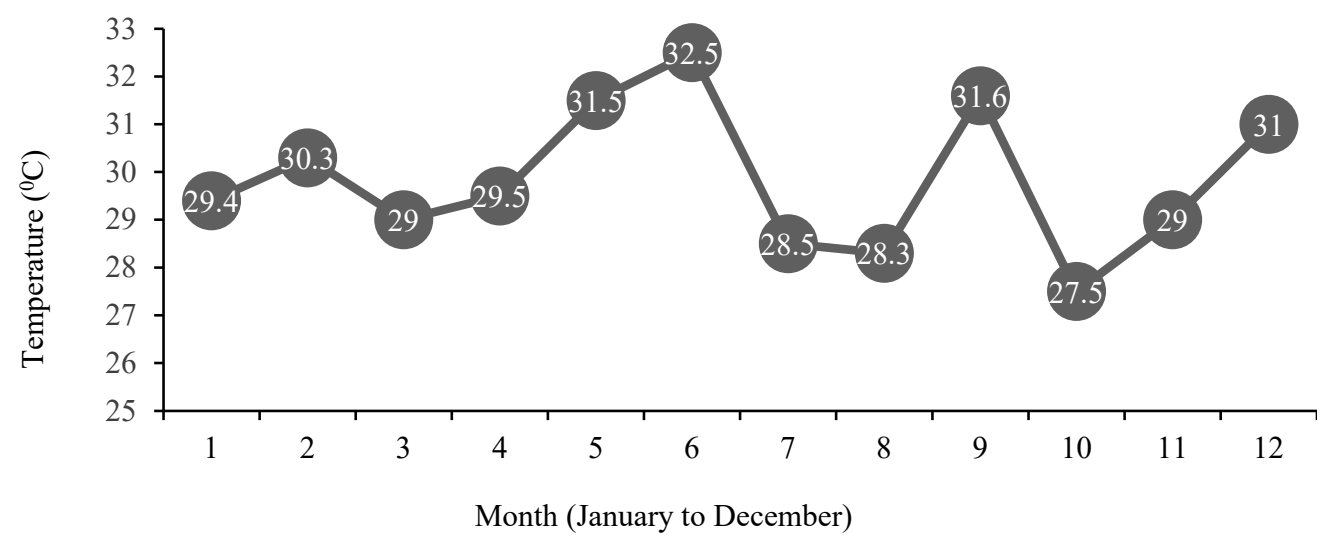

Fig. 6. Monthly fluctuation of temperature in the waters of Pabean Bay, West Java.

Based on the $b$ value test with the t-test, it was found that the Tropical Sand Goby's b value was equal to 3, meaning that the growth pattern of the Sand Goby fish was isometric $(b=3)$, that is, the increase in weight was similar to the increase in length of the fish. The average relative condition factor is 1.028 , with a monthly range of 0.798 to 1.322 (Figure 4).

Two critical parameters on water quality, namely temperature and dissolved oxygen which was monitored for 12 months of observation, can be seen in Figures 5 and 6. Other water quality parameters are $\mathrm{pH}$ and salinity. The data for these two parameters during 12 months of observation was in the range of 6.5 to 8 for $\mathrm{pH}$, while for salinity, it was 25 to 32 parts per thousand (ppt).

\section{Discussion}

The fish's range of length and weight in Pabean Bay is similar to the Tropical Sand Goby, commonly found in other areas, such as in Payra River, Southern Bangladesh. This fish measuring in the length of 3.6-18.3 cm, weight 0.62-51.61 gram [21], and the mangrove forest of Zhanjiang, measuring in the length of 5.9-13 cm and weighing 2.1-29.8 grams [22], and in the East China sea, measuring in 7.2-13.8 cm with a weight of 4.0-30.0 grams [23].

$L W R$ in Pabean Bay has a value of $\mathrm{b}=3.0356$, which indicates an isometric growth pattern which means that the increase in weight is the same as the increase in fish length. In the other three areas mentioned above, the value is in the range of $2.84-3.17$, but there is no information regarding the growth pattern. However, [24], the content of $b$ values remains within the expected range of 2.5-3.5. The exponential value (b) of LWR between fish species above is closely related to ontogenetic development, age differences, gonad maturity, sex, geographical location and environmental conditions, gastric fullness, diseases, and stains of the parasite [25].

Furthermore, the relative condition of this fish cannot be compared with the other three areas, hence making it the first information about this fish. The fluctuating monthly condition factor is closely related to water quality, especially the dissolved oxygen content in the waters of Pabean Bay. The peak point of the condition factor during the year is in March, August, and November (Figure 3), which is in line with the average dissolved oxygen content in the same month, with a range of values from 7.3 to $7.7 \mathrm{ppm}$. (Figure 5). Waters with good oxygen content $(>5 \mathrm{ppm})$ indicate that these waters can support the growth and development of existing biota. The solubility of oxygen increases as the temperature of the waters decreases. 
Although this data was implemented, it needed creation for further research on this fish, which is comprehensive in ecology and biology and its relation to the environment. It is hoped that the present work will be helpful for future research related to trophic ecology and highlight the need to increase the study of the interaction between fish species in Pabean Bay.

\section{Conclusion}

The growth pattern of tropical sand goby is isometric $(b=3)$, modeled by the equation of $\mathrm{W}=$ $9 \times 10^{-6} \mathrm{~L}^{-3.0356}$. The monthly relative condition factor ranged from 0.798 to 1.322 (average: 1.028). The total length and weight of the sample fish ranged respectively from 43-148 $\mathrm{mm}$ and $0.60-30.28$ grams.

\section{References}

1. C.P. Le Cren, JSTOR 20, 201-219 (1951)

2. W. Kimmerer, S.R. Avent, S.M. Bollens, F. Feyrer, L.F. Grimaldo, B. Moyle, et al, Trans. Am. Fish. Soc. 134, 481-495 (2005)

3. T.D. Harisson. J. Appl. Ichthyol. 17, 46-48 (2001)

4. J. Dulčić, B. Glamuzina, J. Appl. Ichthyol. 22, 254-256 (2006)

5. T. Giarrizzo, A.J. Silva de Jesus, E.C. Lameira, J.B. Araujo de Almeida, V. Isaac, U. Saint-Paul, J. Appl. Ichthyol. 22, 325-327 (2006)

6. E.F. Balart, A. Gonzalez-Cabello, R.C. Romero-Ponce, A. Zayas-Alvarez, M. CalderonParra, L. Campos-Davila, et al, J. Appl. Ichthyol. 22, 316-318 (2006)

7. T. Bok, I.K. Oray, Col. Vol. Sci. Pap. ICCAT. 52, 708-718 (2001)

8. M. Šantić, A. Pallaoro, I. Jardas, J. Appl. Ichthyol. 22, 214-217 (2006)

9. B. Zorica, G. Sinovčić, A. Pallaoro, V. Čikeš Keč. J. Appl. Ichthyol. 22, 260-263 (2006)

10. G. Metin, A.T. İlkyaz, H.T. Kinacigil. J. Appl. Ichthyol. 22, 288-289 (2006)

11. R.N. Aini, N. Probosunu, E. Setyobudi. E3S Web Conf. 147, 02006 (2020)

12. G.V. Nikolsky, Theory of population dynamic as a biological background for rational exploitation and management of fishery resources (Oliver and Boyd Publisher, Edinburgh, 1969)

13. A.H. Weatherley, S.C. Rogers, In S.D. Gerking (ed.), Ecology of freshwater fish production (Blackwell Scientific Publication, Oxford, 1978)

14. M.Y. Hossain, Z.F. Ahmed, P.M. Leunda, S. Jasmine, J. Oscoz, R. Miranda, et al., J. Appl. Ichthyol. 22, 304-307 (2006)

15. F. Ribeiro, P.K. Crain, P.B. Moyle, Hydrobiologia 527, 77-84 (2004)

16. M. De Los, A.P. Lizama, A.M. Ambrósio, Braz. J. Biol. 62, 113-124 (2002)

17. G. Knaepkens, D. Knapen, L. Bervoets, B. Hanfling, E. Verheyen, E. Eens, Heredity 89, 280-287 (2002)

18. H. Yeldan, D. Avsar, Turk J Zool. 24, 173-182 (2000)

19. J.A. Jenkins, USGS Open-File Report 1323, 1-47 (2004)

20. S.J.M. Blaber, Fish and fisheries of tropical estuaries (Chapman \& Hall, London, 1997)

21. A. Nahar, M.A. Hanif, M.A.B. Siddik, M.R. Chaklader, M.A. Islam, J. Appl. Ichthyol. 34, 785-787 (2017)

22. W. Xiong, G.P. Zhu, Z.L. Wang, N. Ye, J. Appl Ichthyol. 34, 167-168 (2017) 
23. Q. Wang, C.Y. Sha, J.Q. Zhang, D.F. Zhang, J. Appl. Ichthyol. 33, 853-854 (2017)

24. R. Froese, J. Appl. Ichthyol. 22, 241-253 (2006)

25. M.F. Rahardjo, C.P.H. Simanjuntak, JIPPI 15, 135-140 (2008) 